EDUCATION

Research, Innovation and Solutions on-line ${ }^{(}$
PSYCHOLOGY

I+D+i
Electronic Journal of Research

in Educational Psychology

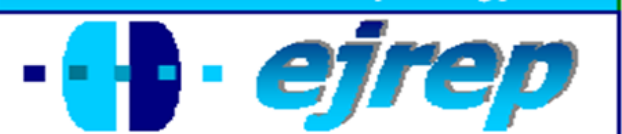

Editorial EOS

\title{
Burnout among Turkish high school teachers working in Turkey and abroad: A comparative study
}

\section{Ismail Aydogan', Ahmet Atilla Dogan ${ }^{2}$, Nuran Bayram ${ }^{3}$}

\author{
${ }^{1}$ Faculty of Education, Erciyes University, Kayseri \\ ${ }^{2}$ Open Education Faculty, Anadolu University, Eskisehir \\ ${ }^{3}$ Faculty of Economics and Administrative Sciences, Uludag University, Bursa
}

\section{Turkey}

Correspondence: Nuran Bayram. Uludag University, Faculty of Economics and Administrative Sciences Department of Econometrics, 16059 Bursa. TURKEY. E-mail: nuranb@uludag.edu.tr 


\begin{abstract}
Introduction. The purpose of this study was to examine perceived levels of burnout among Turkish high school teachers working in Turkey and abroad.

Method. A total of 255 Turkish teachers working at public schools in Germany ( $\mathrm{n}=78$ ), Cyprus ( $\mathrm{n}=94)$ and Turkey $(\mathrm{n}=83)$ comprised our study group. In Germany and Cyprus, the participants were selected from different public high schools in different cities where Turkish teachers taught the Turkish language. In Turkey, the participants were all teachers in one public high school. Participation was voluntary. Participants filled out questionnaires anonymously. Burnout was measured using the Shirom-Melamed Burnout Measure.

Results. Eighty point eight percent of participants from Germany, 84.0\% from Cyprus and $81.9 \%$ from Turkey were satisfied with their workplace. The mean burnout scores were $2.78 \pm 0.98,3.22 \pm 1.03$ and $2.67 \pm 1.07$ for participants from Germany, Cyprus and Turkey, respectively. Variance analysis showed no difference regarding burnout among teachers working in Germany and Turkey, but those working in Cyprus had higher burnout scores. Among the teachers working in Turkey, demographic factors were not found to affect burnout. For the participants from Turkey and Cyprus, depression was found to be an important factor in burnout, whereas for the participants from Germany, job satisfaction had greater significance.
\end{abstract}

Discussion. We found that burnout is a common problem among Turkish teachers working both in Turkey and abroad. According to their mean burnout scores, we did not find significant differences between teachers working in Turkey and Germany, but those working in Cyprus had significantly higher scores.

Keywords: Burnout, high school teachers, Shirom-Melamed Burnout Measure, working abroad.

Received: 04/26/09 Initial Acceptance: 04/27/09 Final Acceptance: 09/22/09 


\section{El desgaste del profesorado turco de educación secundaria que trabaja en Turquía y en el extranjero: un estudio comparativo Resumen}

Introducción. El objetivo de este estudio fue examinar los niveles de desgaste percibido entre el profesorado turco de educación secundaria que trabajan en el extranjero.

Método. El grupo de nuestro estudio consistió de un total de 255 profesores turcos que trabajaban en las escuelas públicas en Alemania $(n=78)$, Chipre $(n=94)$ y Turquía $(n=83)$. En Alemania y Chipre, los participantes fueron seleccionados de diferentes escuelas secundarias públicas en distintas ciudades donde los profesores turcos enseñaban el idioma turco. En Turquía, todos los participantes eran profesores de una escuela secundaria pública. La participación fue voluntaria y los participantes rellenaron los cuestionarios de forma anónima. El desgaste se midió usando la medida Shirom-Melamed del Desgaste.

Resultados. El 80,8\% de los participantes de Alemania estaban satisfechos con su lugar de trabajo. Este porcentaje fue el caso de Chipre y Turquía, 84,0\% y 81,9\% respectivamente. El promedio de las puntuaciones de cansancio fueron $2,78 \pm 0,98 ; 3,22 \pm 1,03$ y 2,67 $\pm 1,07$ para los participantes de Alemania, Chipre y Turquía, respectivamente. El análisis de varianza no mostró ninguna diferencia con relación al desgaste del profesorado que trabajan en Alemania y Turquía, pero los de Chipre tuvieron resultados de cansancio más altos. Para los participantes de Turquía, se encontró que los factores demográficos no afectaban el cansancio. Para los participantes de Turquía y Chipre, la depresión resultó ser un factor importante en el cansancio, mientras que para los participantes de Alemania, la satisfacción en el trabajo tenía una mayor importancia.

Discusión y Conclusiones. Se encontró que el desgaste es un problema común entre el profesorado turco que trabaja en Turquía y en el extranjero. Según los resultados el profesorado de Chipre presentaba las puntuaciones más altas.

Palabras Clave: desgaste, profesorado educación secundaria, medida Shirom-Melamed, trabajo en el extranjero

Recibido: 26/04/09 Aceptación inicial: 27/04/09 Aceptación final: 22/09/09 


\section{Introduction}

Many studies in the literature reveal that teachers have one of the most stressful occupations (Ahghar, 2008; Alkhadher \& Al-Naser, 2006; Bauer, et al., 2006; Betoret, 2006; Borg \& Riding, 1991; Griffith, Steptoe, \& Cropley, 1999; Guglielmi \& Tatrow, 1998; Kokkinos, 2007; Kyriacou \& Sutcliffe, 1978; Travers \& Cooper, 1996; Van Dick \& Wagner 2001). In comparison with other professions, teachers show high levels of burnout (Aris, 2009; Bauer et al., 2006; Guglielmi \& Tatrow, 1998; Kokkinos, 2006; 2007; Koustelios \& Tsigilis, 2005; Langballe, Falkum, Innstrand, \& Aasland, 2006; Maslach, Schaufeli \& Leiter, 2001; Pillay, Goddard \& Wilss, 2005; Pines, 2002; Tsigilis, Zachopoulou \& Grammatikopoulos, 2006).

Burnout among teachers is characterized as having three dimensions (Schaufeli, Enzmann \& Girault, 2003): a physical dimension related to exhaustion as an external symptom, a mental distancing from didactic regular teacher activities and the perception of a reduced professional efficacy. Burnout is the final stage of prolonged and extensive exposure to job stress and can be defined as the inability of the employee to function effectively in their job. It has been identified as a syndrome comprising three distinct elements: emotional exhaustion, depersonalization and diminished personal accomplishment (Maslach, Schaufeli \& Leiter, 2001). Although burnout has been conceptualized as a three-dimension syndrome, some authors agree that the emotional exhaustion subscale is the essential component of burnout and the other two dimensions are different but theoretically related variables that accompany emotional exhaustion (Shirom \& Ezrachi, 2003).

Despite the vast number of studies in the literature concerning teacher burnout, there are few studies that deal with the burnout of teachers working outside their home country. Alkhadher and Al-Naser (2006) found that North American teachers working in their home country reported higher role insufficiency and interpersonal strain than expatriate teachers working in Kuwait. Another study in the United Kingdom showed that non-native English language teachers were under more stress than native teachers (Mousavi, 2007). A recent study indicated that, when measuring burnout levels of teachers holding Canadian citizenship, international teachers display a lower level of burnout than country of origin teachers. Also, international teachers were less prone to emotional exhaustion, dehumanization, feelings of being overwhelmed and loss of interest (Coulter \& Abney, 2009). Another study compared the experienced occupational stress among Indians working in India and in the Sultanate of 
Oman. It was found that Indian expatriates experienced more stress than their counterparts working in India (Deosthalee, 2002). Soylu (2007) mentioned that the effect of foreign employee status on perceived stress was fully mediated by residential insecurity, job insecurity, local social networks, role ambiguity and perceived discrimination. In their controlled longitudinal study, Anderzen and Arnetz (1997) argued that mental well-being decreased in the expatriate group.

There are few studies about burnout experienced by Turkish teachers. However, one such study found high burnout levels where female teachers had higher levels of emotional exhaustion and male teachers experienced higher levels of depersonalization (Gursel, Sunbul $\&$ Sari, 2002). Another study of Turkish high school teachers found no statistically significant differences between male and female teachers in terms of emotional exhaustion and depersonalization; the mean burnout scores according to the Maslach Burnout Inventory were lower than those for developed countries (Demirel, Guler, Tokatmis, Ozdemir, \& Sezer, 2005).

\section{Aims and hypotheses}

This study was conducted to determine whether the burnout levels of Turkish teachers working abroad were identical to those of teachers working in their country of origin. It also aimed to determine whether expatriate and country of origin teachers reported varying levels of burnout for each burnout component. We wanted to assess if there was a significant relationship between teachers' demographic characteristics and the degree of burnout. To address these aims, the following null hypotheses were investigated:

a) There is no statistically significant difference in overall burnout levels between expatriate teachers and those teaching in their country of origin.

b) There is no statistically significant difference in emotional exhaustion, physical fatigue and cognitive weariness levels between expatriate teachers and those teaching in their country of origin.

c) There is no statistically significant relationship between demographic characteristics (gender, age, number of years worked years as a teacher, number of years working in the current school) and burnout level in teachers. 


\section{Method}

\section{Participants and Procedure}

All participants were Turkish citizens, appointed by the Turkish Ministry of Education, and were full time teachers at public high schools, teaching students between 15-18 ages. In this study, we focused on three groups of teachers. One group of teachers was working in Turkey and the other two groups were working in Cyprus and Germany. The expatriate teachers were responsible for teaching the Turkish language. Teachers working in the country of origin were selected from one public high school in a small town located in Western Turkey. Expatriate teachers were selected from different public high schools in different cities in Cyprus and Germany. Approval for this study was given by the school principals. For the country of origin sample, the corresponding high school was visited by the researchers on a given date and a meeting was arranged. After the purpose of the study was explained, printed questionnaires were distributed to every teacher who took part in the meeting.

After a while, the completed questionnaires were collected. All the questionnaires were anonymous and those who did not want to participate were excluded from the study. For the expatriate teachers' samples (Cyprus and Germany), we informed the school principals about our study by standard mail or e-mail. After receiving their approval, we sent the printed questionnaires. The questionnaires were distributed and collected by the school office staff and only Turkish expatriate teachers participated. Questionnaires were filled in without identification marks and those who did not want to participate were excluded. Completed questionnaires were sent back to us by school office staff using stamped self-addressed envelopes. At the corresponding high school in the country of origin, there were a total of 110 teachers. There were 10 teachers absent on the study day and 17 teachers who did not want to participate. Therefore, we collected data from 83 teachers in Turkey. Of the Turkish expatriate teachers, 8 from Cyprus and 15 from Germany did not want to participate and were thus excluded. Furthermore, 5 questionnaires from Cyprus and 6 from Germany were missing data and were also excluded. Ultimately, we were able to collect the data of 94 Turkish expatriate teachers from Cyprus and 78 from Germany. 


\section{Instruments}

We measured burnout, the opposite state of burnout (namely vigor), a statement which is related to burnout and vigor (namely job satisfaction) and the psychological consequences of burnout in terms of depression, anxiety and stress. We also collected demographic data for each participant, including participants' age, gender, number of years in the teaching profession, number of years in the corresponding school, satisfaction with the workplace (yes, no) and the location of employment (expatriate or country of origin).

Burnout: To measure burnout, we used the Turkish version of the Shirom-Melamed Burnout Measure (SMBM), translated by Alanyali (2006). This 12-item questionnaire evaluates three burnout dimensions: physical fatigue (PF) (4 items, e.g., "I feel physically drained"), emotional exhaustion (EE) (4 items, e.g., "I feel emotionally burned out at work") and cognitive weariness (CW) (4 items, e.g., "I have difficulty thinking about complex things"). Responses are rated on a 7-point Likert scale, ranging from 1 for never to 7 for always (Melamed, et al., 1999; Shirom, 2003).

Vigor: To measure vigor, we used the Turkish version of the Shirom-Melamed Vigor Measure (SMVM), translated into Turkish by Alanyali (2006). The SMVM asks respondents to report the frequency of recently experienced energetic feelings at work. It has 14 items, 5 for physical strength (PS), 4 for emotional energy (EEn) and 5 for cognitive liveliness (CL) subscales. Each respondent is requested to indicate the frequency of experiencing each of the feelings described during the last 30 workdays. All items are scored on a 7-point frequency scale, ranging from 1 for never to 7 for always (Melamed, et al., 1999; Shirom, 2008).

Job satisfaction: To determine job satisfaction, we used the Turkish version of the Minnesota Job Satisfaction Scale (MJSS) developed by Weiss, Davis, England and Lofquist (1967). This scale has 20 items yielding three summary scores: intrinsic (IN), extrinsic (EX) and total job satisfaction. Responses are rated on a 5-point Likert scale, ranging from 1 for not satisfied to 5 for very satisfied. The highest point of this scale is 100 and the lowest 20 . High scores mean greater job satisfaction.

Depression, anxiety and stress: We used the Turkish version of DASS-42 (Uncu, Bayram \& Bilgel, 2007). The original scale developed by Lovibond and Lovibond (1995a; 
$1995 b$ ) is a 42-item instrument measuring current (within the past week) symptoms of depression, anxiety and stress. Each of the three scales consists of 14 items that are answered using a 0-3 scale, where $0=$ did not apply to me at all and $3=$ applied to me very much or most of the time. (The range of possible scores for each scale is 0-42.) Scores considered in the normal range are 0-9 for depression, 0-7 for anxiety and 0-14 for stress. Scores above these ranges indicate the degree of the problem from mild to extreme.

The internal consistency (Cronbach $\alpha$ ) of study instruments was found to be high, varying between $0.84-0.96$.

\section{Statistical Analysis}

Descriptive statistical, hierarchical regression and variance analyses were performed on a personal computer using SPSS, version 16.0.

\section{Results}

Of the total 255 participants, 67.5\% were working in Cyprus and Germany. The mean (mean $\pm \mathrm{SD}$ ) age for the teachers working in the country of origin was $38.00 \pm 6.96$ years, whereas for the expatriate teachers working in Cyprus and Germany it was $37.95 \pm 6.74$ and $45.82 \pm 10.42$ years, respectively. Turkish teachers working in Germany were older than those working in Cyprus and Turkey. The mean working period as a teacher was found to be $13.34 \pm 6.42$ years for teachers in the country of origin and $13.62 \pm 6.52$ years for teachers working in Cyprus. Turkish teachers working in Germany had worked for longer $(18.44 \pm 10.90)$. Similar results were found for the mean working years in the current school: $6.14 \pm 4.95$ for Turkish teachers in the country of origin, $6.29 \pm 4.12$ for those in Cyprus and $10.05 \pm 8.63$ years for those in Germany. Eighty two point four percent of all participants reported being satisfied with their current workplace. Among the country of origin teachers, this percentage was $81.9 \%$. Table 1 shows the distribution of the study participants according to their demographic data. 
Table 1. Distribution of the study participants by demographic characteristics and work place satisfaction

\begin{tabular}{|c|c|c|c|c|c|c|c|c|}
\hline \multirow[t]{3}{*}{ Demographic characteristics } & \multirow{2}{*}{\multicolumn{2}{|c|}{$\begin{array}{c}\begin{array}{c}\text { Country of ori- } \\
\text { gin teachers }\end{array} \\
\text { Turkey }\end{array}$}} & \multicolumn{4}{|c|}{ Expatriate teachers } & \multirow{2}{*}{\multicolumn{2}{|c|}{ Total }} \\
\hline & & & \multicolumn{2}{|c|}{ Cyprus } & \multicolumn{2}{|c|}{ Germany } & & \\
\hline & $\mathrm{N}$ & $\%$ & $\mathrm{~N}$ & $\%$ & $\mathrm{~N}$ & $\%$ & $\mathrm{~N}$ & $\%$ \\
\hline \multicolumn{9}{|l|}{ Gender } \\
\hline Female & 46 & 55.4 & 46 & 48.9 & 40 & 51.3 & 132 & 51.8 \\
\hline Male & 37 & 44.6 & 48 & 51.1 & 38 & 48.7 & 123 & 48.2 \\
\hline Total & 83 & 100.0 & 94 & 100.0 & 78 & 100.0 & 255 & 100.0 \\
\hline \multicolumn{9}{|l|}{ Age groups } \\
\hline $20-29$ & 10 & 12.0 & 12 & 12.8 & 16 & 20.5 & 38 & 14.9 \\
\hline $30-39$ & 37 & 44.6 & 44 & 46.8 & 19 & 24.4 & 100 & 39.2 \\
\hline $40-49$ & 31 & 37.3 & 33 & 35.1 & 24 & 30.8 & 88 & 34.5 \\
\hline $50-59$ & 5 & 6.1 & 5 & 5.3 & 19 & 24.3 & 29 & 11.4 \\
\hline Total & 83 & 100.0 & 94 & 100.0 & 78 & 100.0 & 255 & 100.0 \\
\hline \multicolumn{9}{|l|}{ Working years } \\
\hline $1-4$ & 7 & 8.4 & 6 & 6.4 & 7 & 8.9 & 20 & 7.8 \\
\hline $5-9$ & 11 & 13.3 & 22 & 23.4 & 16 & 20.5 & 49 & 19.2 \\
\hline $10-14$ & 33 & 39.6 & 25 & 26.6 & 11 & 14.2 & 69 & 27.1 \\
\hline $15-19$ & 21 & 25.4 & 29 & 30.8 & 12 & 15.4 & 62 & 24.3 \\
\hline 20 and more & 11 & 13.3 & 12 & 12.8 & 32 & 41.0 & 55 & 21.6 \\
\hline Total & 83 & 100.0 & 94 & 100.0 & 78 & 100.0 & 255 & 100.0 \\
\hline \multicolumn{9}{|c|}{ Working years in the current school } \\
\hline $1-4$ & 39 & 46.9 & 45 & 47.9 & 28 & 35.8 & 112 & 43.9 \\
\hline $5-9$ & 25 & 30.2 & 26 & 27.7 & 18 & 23.2 & 69 & 27.1 \\
\hline $10-14$ & 15 & 18.1 & 19 & 20.2 & 14 & 17.9 & 48 & 18.8 \\
\hline $15-19$ & 3 & 3.6 & 3 & 3.1 & 7 & 8.9 & 13 & 5.1 \\
\hline 20 and more & 1 & 1.2 & 1 & 1.1 & 11 & 14.2 & 13 & 5.1 \\
\hline Total & 83 & 100.0 & 94 & 100.0 & 78 & 100.0 & 255 & 100.0 \\
\hline \multicolumn{9}{|l|}{ Work place satisfaction } \\
\hline Yes & 68 & 81.9 & 79 & 84.0 & 63 & 80.8 & 210 & 82.4 \\
\hline No & 15 & 18.1 & 15 & 16.0 & 15 & 19.2 & 45 & 17.6 \\
\hline Total & 83 & 100.0 & 94 & 100.0 & 78 & 100.0 & 255 & 100.0 \\
\hline
\end{tabular}

The highest mean burnout, depression, anxiety and stress scores were found among teachers working in Cyprus. Turkish teachers working in Germany had the highest mean vigor score. Table 2 shows the mean scores of burnout, vigor, job satisfaction, depression, anxiety and stress among teachers working in Turkey, Cyprus and Germany. 
Table 2. Mean burnout, vigor, job satisfaction, depression, anxiety and stress scores of participants

\begin{tabular}{lcccccc}
\hline \multirow{2}{*}{ Measure } & \multicolumn{2}{c}{ Turkey $(\mathrm{n}=83)$} & \multicolumn{2}{c}{ Cyprus $(\mathrm{n}=94)$} & \multicolumn{2}{c}{ Germany $(\mathrm{n}=78)$} \\
\cline { 2 - 7 } & Mean & SD & Mean & SD & Mean & SD \\
\hline Burnout & 2.67 & 1.07 & 3.22 & 1.03 & 2.78 & .98 \\
Vigor & 5.03 & 1.06 & 5.04 & 1.05 & 5.18 & .99 \\
Job Satisfaction & 74.98 & 12.09 & 75.03 & 12.27 & 74.67 & 10.26 \\
Depression & 7.23 & 6.26 & 11.82 & 8.11 & 6.79 & 5.76 \\
Anxiety & 6.71 & 5.31 & 9.33 & 7.84 & 6.31 & 4.93 \\
Stress & 12.13 & 6.28 & 14.41 & 7.85 & 12.06 & 6.46 \\
\hline
\end{tabular}

In terms of total burnout, there was no statistically significant difference between Turkish teachers working in Turkey and Germany, whereas those working in Cyprus had higher scores. Similar results were found for the emotional exhaustion and cognitive weariness components of burnout and for depression, anxiety and stress scores. In terms of vigor and job satisfaction, there was no statistically significant difference among the three groups of teachers. Table 3 shows the results of the variance analysis.

According to the mean burnout scores, 35 teachers working in Turkey, 45 teachers working in Cyprus and 37 teachers working in Germany had higher total burnout scores than the mean values of their corresponding groups. Table 4 shows the $\%$ distribution of teachers with higher burnout and lower vigor scores than the mean scores of their corresponding groups. 
Table 3. Mean (mean \pm SD) burnout, vigor, job satisfaction scores with their sub-domains and mean depression anxiety and stress scores of the study participants according to the working country and the analysis of variance

\begin{tabular}{lcccccc}
\hline Variables & $\begin{array}{c}\text { Turkey } \\
\mathrm{N}=83\end{array}$ & $\begin{array}{c}\text { Cyprus } \\
\mathrm{N}=94\end{array}$ & $\begin{array}{c}\text { Germany } \\
\mathrm{N}=78\end{array}$ & $F$ & $p$ & Post Hoc \\
\hline Burnout (B) & $2.67 \pm 1.07$ & $3.22 \pm 1.03$ & $2.78 \pm 0.98$ & 7.276 & .001 & $\mathrm{C}>\mathrm{T}=\mathrm{G}$ \\
$\mathrm{PF}$ & $3.10 \pm 1.18$ & $3.38 \pm 0.95$ & $3.40 \pm 1.16$ & 1.972 & .141 & - \\
$\mathrm{EE}$ & $2.58 \pm 1.30$ & $3.30 \pm 1.25$ & $2.58 \pm 1.17$ & 9.823 & .000 & $\mathrm{C}>\mathrm{T}=\mathrm{G}$ \\
$\mathrm{CW}$ & $2.32 \pm 1.14$ & $3.00 \pm 1.19$ & $2.36 \pm 1.13$ & 9.668 & .000 & $\mathrm{C}>\mathrm{T}=\mathrm{G}$ \\
\hline Vigor $($ V) & $5.03 \pm 1.06$ & $5.04 \pm 1.05$ & $5.18 \pm 0.99$ & .525 & .592 & - \\
$\mathrm{PS}$ & $4.87 \pm 1.21$ & $4.91 \pm 1.23$ & $4.84 \pm 1.18$ & .081 & .922 & - \\
EEn & $5.31 \pm 1.21$ & $5.19 \pm 1.11$ & $5.53 \pm 1.09$ & 1.884 & .154 & - \\
$\mathrm{CL}$ & $4.97 \pm 1.10$ & $5.05 \pm 0.99$ & $5.25 \pm 1.11$ & 1.468 & .232 & - \\
\hline Job Satisfaction $(J S)$ & $74.98 \pm 12.09$ & $75.03 \pm 12.27$ & $74.67 \pm 10.26$ & .022 & .978 & - \\
$\mathrm{IN}$ & $47.62 \pm 7.18$ & $47.40 \pm 7.76$ & $48.47 \pm 6.12$ & .521 & .595 & - \\
EX & $27.36 \pm 6.02$ & $27.62 \pm 5.49$ & $26.20 \pm 5.34$ & 1.489 & .228 & - \\
\hline Depression (D) & $7.23 \pm 6.27$ & $11.82 \pm 8.11$ & $6.79 \pm 5.76$ & 14.565 & .000 & $\mathrm{C}>\mathrm{T}=\mathrm{G}$ \\
Anxiety (A) & $6.71 \pm 5.31$ & $9.33 \pm 7.85$ & $6.31 \pm 4.93$ & 6.063 & .003 & $\mathrm{C}>\mathrm{T}=\mathrm{G}$ \\
Stress (S) & $12.13 \pm 6.28$ & $14.41 \pm 7.86$ & $12.06 \pm 6.46$ & 3.292 & .039 & $\mathrm{C}>\mathrm{T}=\mathrm{G}$ \\
\hline
\end{tabular}

PF: Physical Fatigue; EE: Emotional Exhaustion; CW: Cognitive Weariness; PS: Physical Strength, EEn: Emotional Energy; CL: Cognitive Liveliness; IN: Intrinsic; EX: Extrinsic

Table 4. Distribution (\%) of teachers with higher and same or lower burnout scores compared to the group's mean burnout score and distribution (\%) of teachers with lower and same or higher vigor scores compared to the group's mean vigor score

\begin{tabular}{|c|c|c|c|c|c|c|c|}
\hline & & \multicolumn{6}{|c|}{$\%$ Distribution of teachers } \\
\hline & & \multirow{2}{*}{\multicolumn{2}{|c|}{$\begin{array}{c}\text { Turkey }(\mathrm{n}=83) \\
\text { Mean burnout score }= \\
2.67 \pm 1.07\end{array}$}} & \multirow{2}{*}{\multicolumn{2}{|c|}{$\begin{array}{c}\text { Cyprus }(\mathrm{n}=94) \\
\text { Mean burnout score }= \\
3.22 \pm 1.03\end{array}$}} & \multirow{2}{*}{\multicolumn{2}{|c|}{$\begin{array}{c}\text { Germany }(\mathrm{n}=78) \\
\text { Mean burnout score }= \\
2.78 \pm 0.98\end{array}$}} \\
\hline & & & & & & & \\
\hline \multirow{6}{*}{ 峞占 } & \multirow{4}{*}{$\begin{array}{l}\text { Female } \\
\text { Male } \\
\text { Total }\end{array}$} & Higher & Same or lower & Higher & Same or lower & Higher & Same or lower \\
\hline & & 43.5 & 56.5 & 50.0 & 50.0 & 55.0 & 45.0 \\
\hline & & 40.5 & 59.5 & 45.8 & 54.2 & 39.5 & 60.5 \\
\hline & & 42.2 & 57.8 & 47.8 & 52.2 & 47.4 & 52.6 \\
\hline & & Tul & ey $(n=83)$ & & us $(n=94)$ & $\mathrm{Gel}$ & $\operatorname{any}(n=78)$ \\
\hline & & Mean & $\begin{array}{l}\text { vigor score }= \\
03 \pm 1.06\end{array}$ & Meai & $\begin{array}{l}\text { igor score }= \\
4 \pm 1.05\end{array}$ & Mear & $\begin{array}{l}\text { igor score }= \\
18 \pm 0.99\end{array}$ \\
\hline \multirow{4}{*}{ 告 } & \multirow{4}{*}{$\begin{array}{l}\text { Female } \\
\text { Male } \\
\text { Total }\end{array}$} & Lower & $\begin{array}{c}\text { Same or hig- } \\
\text { her }\end{array}$ & Lower & $\begin{array}{c}\text { Same or hig- } \\
\text { her }\end{array}$ & Lower & $\begin{array}{c}\text { Same or hig- } \\
\text { her }\end{array}$ \\
\hline & & 50.0 & 50.0 & 43.5 & 56.5 & 50.0 & 50.0 \\
\hline & & 40.5 & 59.5 & 52.1 & 47.9 & 47.4 & 52.6 \\
\hline & & 45.8 & 55.2 & 47.8 & 52.2 & 48.7 & 51.3 \\
\hline
\end{tabular}


We built two hierarchical regression models to predict the variables that may be correlated with burnout and vigor. In our first model, we only used the demographic variables and satisfaction with the current workplace. None of these variables was found to affect either burnout or vigor among Turkish teachers in the country of origin. For the expatriate teachers in Cyprus, the number of years worked in the current school and satisfaction with the current workplace were found to be related to burnout. Indeed, $23 \%$ of the variance of the burnout measure could be explained by these two variables. There was a negative relationship between satisfaction with the current workplace and burnout, and a positive relationship between the numbers of years worked in the current school and burnout. For the expatriates in Germany, $23 \%$ of the variance of burnout could be explained by gender and satisfaction with the current workplace. Being a female teacher and being dissatisfied with the current workplace were found to be important factors affecting burnout. For the expatriate teachers in $\mathrm{Cy}-$ prus, $34 \%$ of the variance in vigor could be explained by being a female teacher and being satisfied with the current workplace. For the teachers in Germany, the explained variance in vigor, which could be explained by being satisfied with the current workplace, was found to be $23 \%$. Table 5 shows the regression model for burnout and vigor.

In our second regression model, job satisfaction, depression, anxiety and stress scores of the participants were added into the analysis. The variance of burnout and vigor among the teachers working in Turkey was significant and $24 \%$ of the variance for burnout could be explained by depression. We found a positive relationship between depression and burnout. A similar significant positive relationship was found between job satisfaction and vigor, which accounted for about $23 \%$ of the variance for vigor. For the expatriate teachers in Cyprus, $57 \%$ of the variance for burnout could be explained by depression. Fifty-eight percent of the variance for vigor could be explained by job satisfaction and anxiety, whereas higher job satisfaction and lower anxiety meant higher vigor. For the teachers working in Germany, $55 \%$ of the variance for burnout could be explained by job satisfaction. Fifty-three percent of the variance for vigor could be explained by job satisfaction and anxiety, whereas lower job satisfaction meant high burnout and high job satisfaction, and lower anxiety meant high vigor. 
Table 5. Hierarchical regression analysis predicting burnout and vigor for countries

\begin{tabular}{|c|c|c|c|c|c|c|c|}
\hline & & \multicolumn{2}{|c|}{ Turkey } & \multicolumn{2}{|c|}{ Cyprus } & \multicolumn{2}{|c|}{ Germany } \\
\hline & Predictors & Burnout $^{\mathrm{a}}$ & Vigor $^{a}$ & Burnout $^{\mathrm{a}}$ & Vigor $^{a}$ & Burnout $^{\mathrm{a}}$ & Vigor $^{\mathrm{a}}$ \\
\hline \multirow[t]{2}{*}{ Step 1} & Gender & -.034 & -.022 & .016 & $-.315^{* *}$ & $-.215^{*}$ & .081 \\
\hline & Age & .070 & -.029 & .121 & -.319 & .157 & .029 \\
\hline \multirow{4}{*}{ 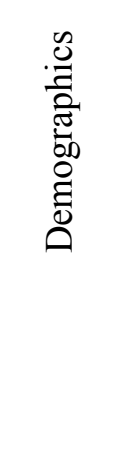 } & $\begin{array}{l}\text { Working years } \\
\text { in current } \\
\text { school }\end{array}$ & -.167 & .204 & $.318^{* *}$ & -.195 & .122 & .024 \\
\hline & $\begin{array}{l}\text { Working years } \\
\text { as teacher }\end{array}$ & .176 & -.157 & -.168 & .336 & -.132 & -.002 \\
\hline & $\begin{array}{l}\text { Satisfaction of } \\
\text { working place }\end{array}$ & -.110 & $.236^{*}$ & $-.297^{* *}$ & $.368^{* * *}$ & $-.397^{* * *}$ & $.464^{* * *}$ \\
\hline & $\mathrm{R}^{2}$ & 0.05 & 0.09 & $0.23^{* * *}$ & $0.34^{* * *}$ & $0.23^{* *}$ & $0.23^{* *}$ \\
\hline \multirow[t]{3}{*}{ Step 2} & Gender & -.115 & .053 & -.096 & -.074 & $-.207^{*}$ & .086 \\
\hline & Age & .043 & -.097 & -.121 & -.166 & .110 & .081 \\
\hline & $\begin{array}{l}\text { Working years } \\
\text { in current } \\
\text { school }\end{array}$ & -.095 & .123 & .083 & .022 & .013 & .107 \\
\hline \multirow{8}{*}{ 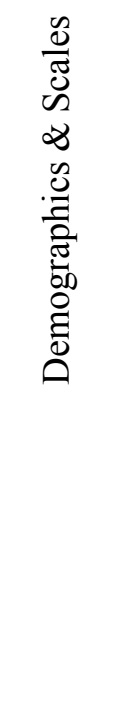 } & $\begin{array}{l}\text { Working years } \\
\text { as teacher }\end{array}$ & .090 & -.011 & .131 & .131 & .022 & -.136 \\
\hline & $\begin{array}{l}\text { Satisfaction of } \\
\text { workplace }\end{array}$ & -.004 & .115 & -.082 & .081 & -.014 & .138 \\
\hline & Job satisfaction & -.062 & $.286^{*}$ & -.157 & $.351^{* * *}$ & $-.313^{* *}$ & $.292^{*}$ \\
\hline & Depression & $.585^{* * *}$ & -.228 & $.443^{*}$ & .214 & .287 & -.227 \\
\hline & Anxiety & .059 & -.217 & .278 & $-.643^{* * *}$ & .126 & $-.317^{*}$ \\
\hline & Stress & -.037 & .329 & -.076 & .020 & .103 & .084 \\
\hline & $\mathrm{R}^{2}$ & $0.24^{* * *}$ & $0.23^{*}$ & $0.57^{* * *}$ & $0.58^{* * *}$ & $0.55^{* * *}$ & $0.53^{* * *}$ \\
\hline & $\mathrm{R}^{2}$ Change & 0.19 & 0.14 & 0.34 & 0.24 & 0.32 & 0.30 \\
\hline
\end{tabular}

\section{Discussion or Conclusions}

Foreign assignments are becoming an important occupational and social issue for employers, employees and their families. Furthermore, expatriate adjustment has received recent scholarly attention and previous studies have revealed that employees experience several 
stressors during the expatriation processes because of difficulty in adjusting to new cultures and customs, lack of contunity in work duties and new colleagues and supervisors, as well as performance appraisal standarts (Anderzen\& Arnetz, 1997; Black, 1988; Mendenhall \& Oddou, 1985; Moore, 1994; Munton, 1990). Teachers on an international assignment must deal with new circumstances as mentioned above. There are few studies in the literature which compare burnout and stress among teachers of working in country of origin and abroad (Coulter \& Abney, 2009; Deosthalee, 2002; Mousavi, 2007). As far as to our knowledge our study is the first one which compares burnout levels of Turkish expatriate and country of origin teachers. Our study showed that burnout is a common problem among Turkish teachers working either in Turkey or abroad. We found that nearly half of the Turkish teachers are suffering from burnout regardless their working places. Some studies performed only among teachers working in Turkey revealed also high burnout levels. For example in their study of teachers and head teachers in Turkey, Gursel, Sunbul and Sari (2002) showed that the levels of depersonalization and personal accomplishment of the three burnout dimensions were high for both groups in Turkish schools. However, another study found that Turkish teachers had lower burnout scores than teachers in developed countries (Demirel et al., 2005).

One of our hypotheses was that there are no significant differences regarding burnout among Turkish teachers in the country of origin and expatriate teachers in Cyprus and Germany. We reject this hypothesis because we found differences among our three groups. These differences occurred among the expatriate teachers in Cyprus-they had higher burnout scores than the teachers working in Turkey and Germany. We found no significant difference regarding burnout scores among Turkish teachers working in Turkey and expatriate teachers working in Germany. The physical fatigue score showed no significant difference among the three groups of teachers. A study of Canadian teachers found that international teachers display lower median values than country of origin teachers for total burnout, as well as for each of the burnout components (Coulter \& Abney, 2009).

Another of our hypothesis was that there is no statistically significant difference in emotional exhaustion, physical fatigue and cognitive weariness levels between expatriate teachers and those teaching in their country of origin. We accepted this for physical fatigue, but rejected it for the emotional exhaustion and cognitive weariness components of burnout. We found significant differences in these burnout components between expatriate and country of origin teachers. This difference occurred among the teachers working in Cyprus - they had 
higher scores both for emotional exhaustion and cognitive weariness than did country of origin teachers and expatriate teachers in Germany. A study of primary school teachers in Cyprus showed that married female teachers were more emotionally exhausted than their married male counterparts. Also, emotional exhaustion for teachers having more than 10 years of teaching experience was greater than for those with less than 10 years of teaching experience (Kokkinos, 2007). We did not find that the number of years of teaching was significantly related to burnout or vigor in any of our three groups of teachers.

Prior studies using the Maslach Burnout Inventory have shown that job satisfaction is negatively correlated with burnout, especially with the emotional exhaustion and depersonalization components (Maslach \& Schaufeli, 1993). Research in educational settings has revealed similar findings. For example, Koustelios and Tsigilis (2005) found a moderate to high correlation between job satisfaction and burnout. They suggested that personal accomplishment and emotional exhaustion are the most important antecedents of burnout among Greek physical education teachers. In this study, we measured overall job satisfaction using the Minnesota Job Satisfaction Scale and found no significant differences among the three groups of teachers. Except among expatriate teachers in Germany, job satisfaction was not correlated with burnout. We found that job satisfaction was positively correlated with vigor in all of the three groups of teachers.

Our final hypothesis was that there is no statistically significant relationship between demographic characteristics and burnout in teachers. We accepted this hypothesis. Only among expatriate teachers in Germany gender was found to be related with burnout-female teachers' burnout levels were higher than males'. Demirel and colleagues (2005) found no significant differences among male and female Turkish teachers in terms of burnout, and Gursel, Sunbul and Sari (2002) pointed to the significantly higher levels of emotional exhaustion among female Turkish teachers. The study by Coulter and Abney (2009) found no correlation between burnout for international and country of origin working Canadian teachers and the various demographic characteristics. They confirmed that burnout affects teachers equally, regardless of age, gender, level of education and number of years in the teaching profession.

To a great extent, our results suggest there are no significant differences in terms of burnout, vigor and job satisfaction between Turkish teachers working in their country of 
origin and those working abroad. The fluctuations in burnout among expatriate teachers in Cyprus should be studied further.

Some limitations regarding the generalizability of the present data should be pointed out. The first limitation relates to the use of self-reported data for all constructs. Experts recommended that this kind of measure should be combined with other more qualitative or observational measures. It could be argued that teachers' responses may be influenced by social values or tendencies. The second major limitation is related to the representativeness of the sample used. Teachers participated on a voluntary basis in this study. They were not selected using a rigorous procedure to ensure the representativeness of the sample. Therefore, generalizing these findings would not be appropriate. The third major limitation relates to the comparison of this study's findings with other similar studies. The vast majority of previous studies used the Maslach Burnout Inventory, whereas we used the Shirom-Melamed Burnout and Vigor measures. However, it has been shown that there is concordance between these different measures (Shirom \& Melamed 2006). Still, some discrepancies may have occurred.

As a conluding statement we can said that burnout among Turkish high school teachers is common. No statistically significant differences were found among expatriate teachers working in Germany and those working in country of origin in terms of burnout levels however expatriate teachers working in Cyprus had higher burnout levels. Similar results were obtained for the depression, stress and anxiety levels. We found no significant differences in terms of job satisfaction and vigor among the studied three groups of teachers. The significantly higher levels of burnout, depression, anxiety and stress among expatriate teachers in Cyprus need to be further studied.

\section{Acknowledgments}

The authors would like to thank Scribendi Inc. (Ontario/Canada) for their professional assistance in proofreading and editing the manuscript. This study has no conflict of interests. 


\section{References}

Ahghar, G. (2008). The role of school organizational climate in occupational stress among secondary school teachers in Tehran. International Journal of Occupational Medicine and Environmental Health, 21, 319-329.

Alanyali, K. (2006). The effects of organizational stress resources on job satisfaction with regard to burnout and vigor measures. Unpublished Master Thesis. Uludag University, Social Sciences Institute, Department of Labour Economics and Industrial Relationships, pp. 101-102. Bursa, Turkey.

Alkhadher, O., \& Al-Naser, H. (2006). Assessing occupational stress, strain and coping for North American teachers in Kuwait. Psychological Reports, 99, 681-690.

Anderzen, I., \& Arnetz, B. (1997). Psychophysiological reactions during the first year of a foreign assignment: results of a controlled longitudinal study. Work \& Stress, 11(4), 304-318.

Aris, N. (2009). Burnout syndrome in educators. Electronic Journal of Research in Educational Psychology, 18, 7(2), 829-848.

Bauer, J., Stamm, A., Virnich, K., Wissing, K.,Müller, U., Wirsching, M., \& Schaarschmidt, U. (2006). Correlation between burnout syndrome and psychological and psychosomatic symptoms among teachers. International Archives of Occupational and Environmental Health, 79, 199-204.

Betoret, F.D. (2006). Stressors, self efficiacy, coping resources, and burnout ampng secondary school teachers in Spain. Educational Psychology, 26, 519-539.

Black, J.S. (1988). Work role transitions: a study of American expatriate managers in Japan. Journal of International Business, 19, 277-294.

Borg, M.G., \& Riding, R.J. (1991). Occupational stress and satisfaction in teaching. British Educational Research Journal, 17, 263-281.

Coulter, M.A., \& Abney, P.C. (2009). A study of burnout in international and country of origin teachers. International Review of Education, 55, 105-121.

Demirel, Y., Guler, N., Tokatmis, A., Ozdemir, D., Sezer, E. (2005). Burnout among high school teachers in Turkey. Middle East Journal of Family Medicine, 3(3),33-36.

Deosthalee, P.G. (2002). Are Indian expatriates in Sultanate of Oman under stres? Journal of Managerial Psychology, 17(6),523-528. 
Griffith, J., Steptoe, A., \& Cropley, M. (1999). An investigation of coping strategies associated with job stress in teachers. British Journal of Educational Psychology, 69, 517531.

Guglielmi, R.S., \& Tatrow, K. (1998). Occupational stress, burnout, and health in teachers. A methodological and theoretical analysis. Review of Educational Research, 68, 61-99.

Gursel, M., Sunbul, A. M., \& Sari, H. (2002). An analysis of burnout and job satisfaction between Turkish headteachers and teachers. European Journal of Psychology of Education, $17(1), 35-46$.

Kokkinos, C.M. (2006). Factor structure and psychometric properties of the Maslach Burnout Inventory-Educators Survey among elementary and secondary school teachers in Cyprus. Stress and Health, 22, 25-33.

Kokkinos, C.M. (2007). Job stressors, personality and burnout in primary school teachers. British Journal of Educational Psychology, 77, 229-243.

Koustelios, A. \& Tsigilis, N. (2005). The relationship between job burnout and job satisfaction among physical education teachers: A multivariate approach. European Physical Education Review, 11(2), 189-203.

Kyriacou, C., \& Sutcliffe, J. (1978). Teacher stress: Prevalence, sources and symptoms. British Journal of Educational Psychology, 48, 159-167.

Langballe, E.M., Falkum, E., Innstrand, S.T., \& Aasland, O.G. (2006). The factorial validity of the Maslach Burnout Inventory- General Survey in representative samples of eight different occupational groups. Journal of Career Assessment, 14(3), 370-384.

Lovibond, S.H., \& Lovibond, P.F. (1995a). Manual for the depression anxiety stress scales. Sydney: Psychology Foundation.

Lovibond, S.H., \& Lovibond, P.F. (1995b). The structure of negative emotional states: comparison of the depression anxiety stres scales (DASS) with the beck depression and anxiety inventories. Behavavioral Research Therapy, 33, 335-343.

Maslach, C. \& Schaufeli, W.B. (1993). Historical and Conceptual Development of Burnout. In W. Schaufeli, C. Maslach and T. Marek (eds) Professional Burnout: Recent Developments in Theory and Research, (1-16). Philadelphia, PA: Taylor and Francis.

Maslach, C., Schaufeli, W.B., \& Leiter, M.P. (2001). Job burnout. Annual Review of Psychology, 52, 397-422.

Melamed, S., Ugarten, U., Shirom, A., Kahana, L., Lerman, Y., \& Froom, P. (1999). Chronic burnout, somatic arousal and elevated cortisol levels. Journal of Psychosomatic Research, 46, 591-598. 
Mendenhall, M., \& Oddou, G. (1985). The dimensions of expatriate acculturation: a review. Academy of Mangement Review, 10, 39-47.

Moore, E.C. (1994). International occupational health care. Journal of Occupational Medicine, 4, 419-427.

Munton, A.G. (1990). Job relocation: stress and the family. Journal of Organizational Behavior, 11, 401-406.

Mousavi, E.S. (2007) Exploring teacher stres in non-native and native teachers of EFL. English Language Teacher Education and Development, 10, 33-41.

Pillay, H., Goddard, R., \& Wilss, L. (2005). Well-being, burnout and competence: implications for teachers. Australian Journal of Teacher Education, 30(2), 22-33.

Pines, A.M. (2002). Tecaher burnout: A psychodynamic existential perspective. Teachers and Teaching: Theory and Practice, 8(2), 121-140.

Schaufeli, W.B, Enzmann, D., \& Girault, N. (2003). Measurement of burnout: a review. In W.B. Schaufeli, C. Maslach \& T. Marekeds (Eds), Professional Burnout: Recent Developments in Theory and Research (169-215). Washington, D.C.: Taylor \& Francis.

Shirom, A., \& Ezrachi, Y. (2003). On the discriminant validity of burnout, depression and anxiety: A re-examination of the burnout measure. Anxiety Stres and Coping, 16(1), 83-97.

Shirom, A. (2003). Job related burnout. In Quick, J.C. and Tetrick, L.E. (Eds.), Handbook of Occupational Health Psychology, (245-265). Washington, DC: APA.

Shirom, A. \& Melamed, S. (2006). A comparison of the construct validity of two burnout measures in two groups of professionals. International Journal of Stress Management, 13, 176-200.

Shirom, A. (2008). Shirom Melamed Burnout Measure. Available at: http://recanati.tau.ac.il/faculty/shirom arie.htm. Retrieved on 26 February, 2009.

Soylu, A. (2007). Foreigners and workplace stress. Journal of Individual Employment Rights, 12(4), 313-327.

Travers, C.J., \& Cooper, C.L. (1996). Teachers under stress. Stress in teaching professions. London: Routledge.

Tsigilis, N., Zachopoulou, E., \& Grammatikopoulos, V. (2006). Job satisfaction and burnout among Greek early educators: A comparison between public and private sector employees. Educational Research and Review, 1(8), 256-261.

Uncu, Y., Bayram, N., \& Bilgel, N. (2007). Job related affective wellbeing among primary health care physicians. European Journal of Public Health, 17(5), 514-519. 
Weiss, D.J., Dawis, R.V., England, G.W., \& Lofquist, L. H. (1967). Manual for the Minnesota Satisfaction Questionnaire. Minnesota: University of Minnesota.

Van Dick, R. \& Wagner, U. (2001). Stres and strain in teaching: A structural equation approach. British Journal of Educational Psychology, 71, 243-259. 